\title{
THE DESIGN AND VERIFICATION OF PROBLEM TEACHING IN SECONDARY VOCATIONAL SCHOOL
}

\author{
L'ubomír ŽÁC̆OK*, Univerzita Mateja Bela v Banskej Bystrici, Slovenská \\ republika
}

Milan BERNÁT, Prešovská univerzita v Prešove, Slovenská republika

Přijato: 10. 4. 2016 / Akceptováno: 27. 5. 2016

Typ článku: Výzkumný článek

DOI: $10.5507 /$ jtie.2016.013

Abstract: The authors of scientific studies analyzing the problem teaching in the current school. In the second part of the study indicate a specific proposal process execution problem teaching in upper secondary education. The last part of a scientific study has an empirical character. This section describes the implementation of the pedagogical experiment. The study authors analyzed qualitative and quantitative data collected implemented within the pedagogical experiment. Using research methods, we found that applying problem teaching in the educational process is justified.

Key words: problem teaching, pupil, pedagogical experiment, design, analysis, secondary vocational schools.

\section{NÁVRH A VERIFIKÁCIA PROBLÉMOVÉHO VYUČOVANIA V STREDNEJ ODBORNEJ ŠKOLE}

Abstrakt: Autori vedeckej štúdie analyzujú problémové vyučovanie v súčasnej škole. V druhej časti štúdie uvádzajú konkrétny návrh postupu realizácie problémového vyučovania vo vyššom strednom vzdelávaní. Posledná čast' vedeckej štúdie má empirický charakter. V tejto časti je uvedený postup realizácie pedagogického experimentu. V závere vedeckej štúdie uvádzajú aj stručný opis riešenia úloh, resp. tvorivej práce žiakov priamo na vyučovacej jednotke. Použitím výskumných metód sme zistili, že aplikovanie problémového vyučovania do edukačného procesu má svoje opodstatnenie.

Kl'účové slová: problémové vyučovanie, žiak, pedagogický experiment, návrh, analýza, stredná odborná škola.

\footnotetext{
*Autor pro korespondenci: lubomir.zacok@umb.sk
} 


\section{1 Úvod}

Problémové vyučovanie zarad’ujeme medzi novšiu koncepciu vyučovania (Turek, 2008. s. 374). V edukačnom procese má svoje prednosti, ale i nedostatky. Vychádzali sme zo známych skutočnosti, že problémové vyučovanie zahŕňa viacej vyučovacích postupov a stratégií, ako je napr. tvorivé myslenie. Naučí sa niekto pracovat's kovom alebo dokáže si zhotovit' (ušit') dámsku sukňu, ak bude počúvat' učitel'a, ako teoreticky rozpráva o ručnom spracovaní kovov alebo o postupe zhotovenia dámskej sukne? Zrejme nie. Tak isto je to s tvorivost'ou. Každý žiak si to musí aj sám vyskúšat', aby to pochopil aj po praktickej stránke. Problémové vyučovanie vel'mi úzko súvisí s tvorivost'ou. Tvorivý žiak sa nedokáže uspokojit' s obvyklými riešeniami, ale hl'adá nové dosial nepoužívané mechanizmy správania. V školskej praxi sa na rozvoj tvorivosti využívajú rôzne tvorivé úlohy. Ciel’om nášho príspevku je analyzovat' problémové vyučovanie a následne aplikovat' problémové vyučovanie do edukačného procesu. Snažili sme sa do návrhu problémového vyučovania zakomponovat' aj tvorivé úlohy. Úlohy sú zadefinované jasne a jednoznačne a zamerané na šest' faktorov tvorivosti (fluenciu, flexibilitu, originalitu, redefinovanie, senzitivitu a elaboráciu).

\section{Použité metódy}

Zámerom autorov pri spracovaní témy vedeckej štúdie bolo objasnit' a vysvetlit' podstatu, negatíva a pozitíva problémového vyučovania $\mathrm{v}$ edukačnom procese. $\mathrm{V}$ empirickej časti sa autori venujú výskumnému problému - do akej miery navrhnuté problémové vyučovanie vplýva na žiakov pri dosahovaní vyšších výkonov v kognitívnej oblasti. $\mathrm{K}$ naplneniu stanoveného zámeru, autori zvolili aj tomu zodpovedajúce metódy. Hlavnými uplatnenými metódami pri štúdiu odborných a vedeckých štúdií, bola metóda analýzy, komparácie a syntézy získaných poznatkov, vývojových tendencií v systéme vzdelávania. Pedagogickým experimentom sme porovnávali skupiny žiakov. V jednej skupine žiakov bola realizovaná výučba tradičnými metódami a v druhej skupine žiakov bola realizovaná výučba s využitím problémového vyučovania. Na porovnanie výkonov žiakov bol použitý neštandardizovaný didaktický test. Didaktický test sme navrhli podl'a autora Ivana Tureka. Na zistenie postojov žiakov $\mathrm{k}$ riešeniu konkrétnych úloh sme zvolili a použili metódu pozorovania činnosti žiakov. Výstupom aplikovania uvedených metód pri spracovaní témy štúdie bola zrealizovaná analýza problémového vyučovania v edukačnom procese. Ďalej sme zistili, že výsledky (výkony žiakov) v kontrolnej a experimentálnej skupine sú rozdielne a štatisticky významné. Pozorovaním žiakov sme zistili vzt’ah žiakov $\mathrm{k}$ riešeniu tvorivých úloh $\mathrm{v}$ rámci problémového vyučovania.

\section{Analýza problémového vyučovania}

Problémové vyučovanie vzniklo koncom 19. storočia v USA a jeho filozofickým základom bol pragmatizmus (Turek, 2008). Pri charakteristike koncepcie praktickej školy sme uviedli, že J. Dewey je okrem iného považovaný za iniciátora požiadavky učit' sa riešením problémov, či už teoretických, alebo praktických, ktoré je potrebné prekonat' na základe tvorivého myslenia a činnosti.

Ako samotný názov koncepcie napovedá, jej podstata spočíva $\mathrm{v}$ riešení problémov na vyučovaní. Kladie vel'ký dôraz na samostatné myslenie a konanie žiaka, nakol'ko sa mu nové 
poznatky nemajú odovzdávat' $\mathrm{v}$ ucelenej, hotovej podobe, ale musí prekonávat' prekážky pri ich hl'adaní, či osvojovaní. Učivo má byt' upravené tak, aby poskytovalo príležitost' na rozmýšlanie, aby nútilo k uvažovaniu. Pri problémovom vyučovaní má byt' značná čast' činnosti učitel’a a žiakov zameraná na organizovanie problémovej situácie, na formulovanie, riešenie, overovanie riešení problémov. Učitel' má riadit' vyučovací proces a poskytovat' žiakom nevyhnutné informácie, aby dokázali získavat' vedomosti neustále sa rozširujúceho sa myslenia hl'adaním spôsobov a prostriedkov riešenia. Žiaci si teda osvojujú nové vedomosti a spôsoby činnosti v problémových situáciách (Bajtoš, 2003).

Pri problémovom vyučovaní je potrebné aby:

- vychádzalo z predchádzajúcich vedomostí a skúseností žiaka,

- nastolený problém bol primeraný veku, vedomostiam, schopnostiam, skúsenostiam,

- po sformulovaní problému boli vyjadrené predpoklady riešenia, hypotézy,

- celý proces bol zavíšený vyriešením problému,

- vyučovanie bolo dynamické.

Pedagogická teória odporúča (Lerner, Okoň, Turek,), aby problémové vyučovanie bol organizované v nasledovných etapách: nastolenie problému, riešenie problému, vyriešenie problému a kontrola riešenia problému.

V úvodnej etape, pri organizovaní problémovej situácie je potrebné nielen vymedzit' problém, ale aj motivovat' žiaka, aby mal snahu hl'adat' riešenia úloh, ktoré nedokáže zaužívanými postupmi vyriešit'. V následnej etape je potrebné analyzovat 'čiastkové $\boldsymbol{t}$ 'ažkosti a prekážky riešenia zadaných úloh. Postupné riešenie čiastkových problémov či už skupinovo, alebo individuálnej predstavuje d’alšiu etapu. Záverečnú etapu problémového vyučovania predstavuje konečné riešenie nastoleného komplexného problému, zhrnutie a zovšeobecnenie riešenia (Petlák, 2004).

Pol'ský pedagóg W. Okoň (1966) určuje učitel'ovi a žiakovi nasledovné aktivity pri organizovaní problémového vyučovania. Učitelovi patrí organizovanie problémových situácií, formulovanie problémov, poskytovanie nevyhnutnej pomoci žiakom pri riešení problémov a pri overovaní tohto riešenia, riadenie procesu systematizácie a upevňovanie takto získaných poznatkov. Žiakovi nachádzanie problémov, formulovanie problémov, riešenie problémových situácií, overovanie výsledkov riešenia.

Ak by sme mali hodnotit' problémové vyučovanie, má podobne ako iné koncepcie svoje pozitíva a negatíva. $Z$ charakteristiky tejto koncepcie vyplýva, že kladie zvýšené nároky na prácu učitela, ktorý organizuje problémové situácie, riadi činnost' žiakov, ale aj na žiaka, od ktorého sa vyžaduje samostatný, tvorivý postup a riešenie rozporu medzi požiadavkami, ktoré vyplývajú z úloh a jeho spôsobilost’ami zadané úlohy riešit'. Za pozitívum môžeme považovat', že pripravuje žiakov na budúci život, $\mathrm{v}$ ktorom sa budú stretávat' $\mathrm{s}$ t'ažkost’ami pri riešení rôznych úloh rôzneho charakteru a na ktoré sa pripravujú osvojovaním si rôznych stratégií riešenia, rozvoj tvorivých schopností, nemenej dôležité je formovanie morálnovôlových vlastností, schopnosti prekonávat' prekážky a spolupracovat' pri riešení problémov. Záverom pripomíname, že nie každé učivo je vhodné vyučovat' riešením problémov a že zadaná úloha nemusí byt' problémom pre všetkých žiakov. 
4 Návrh štruktúry vyučovacej jednotky s využitím problémového vyučovania

Študijný odbor:

Ročník:

Vyučovací predmet:

Tematický celok:

Téma:

Ciel' vyučovacej hodiny:

Typ vyučovacej hodiny:

Počet hodín:

Organizačná forma vyučovania:

Vyučovacie metódy:

Vyučovacie zásady:
Odevný dizajn

prvý

Technológia

Dámska sukňa

Dámska sukňa - návrh modelu sukne

z károvaného materiálu.

Žiak vie využit' károvaný materiál na vytvorenie návrhu sukne. Ovláda konštrukčné riešenia strihov. Vie ich aplikovat' pre konkrétne potreby vytvorenia návrhov sukne. Ovláda technologický postup zhotovenia základnej dámskej sukne.

Kombinovaná hodina, problémová, s využitím faktorov tvorivosti.

Štyri vyučovacie jednotky -4 vyuč. hodiny po 45 minút.

Frontálna, skupinová

Motivačný rozhovor, problémový výklad, heuristická metóda, samostatná práca žiakov.

Zásada primeranosti, uvedomenosti, názornosti, trvácnosti, spojenia teórie s praxou, vedeckosti.

Učebné pomôcky a didaktická technika: Učebnice Technológia 1. roč. SPŠO, PC - prezentácia v PowerPointe s témou Dámska sukňa, základné učebné pomôcky - praktické ukážky vzorkovníkov - rázporkov na sukne, zipsové rázporky, vzorkovníky pásových okrajov na sukne, obrázkový materiál rôznych druhov a modelov sukne, vzorkovník tkanín materiálov.

Všetky odborné predmety $\mathrm{v}$ danom

študijnom odbore - Náuka o materiáloch, Konštrukcia a modelovanie odevov, Navrhovanie a Odevná tvorba. Učivo v týchto predmetoch $\mathrm{v}$ rámci obsahu učiva na seba nadväzuje.

\section{Štruktúra a priebeh vyučovacej jednotky}

Organizačná etapa (3 min.). Zápis do triednej knihy, kontrola prítomnosti žiakov, overit' donesené školské pomôcky a obrázky modelov sukne.

Motivačná etapa (15 min.). Motivačná otázka učitel'a: Čo rozumiete pod pojmom dámska sukňa? Odpoved'žiakov: Sukňa je ženský, vrchný sukňovitý odev, je samostatnou súčast'ou 
odevu pre ženy, rôznym strihovým riešením docielime jej rozmanitost' na každú príležitost'. Motivovat žiakov k záujmu o nové učivo názornými ukážkami vzorkovníkov dielčích častí sukne, zipsových rázporkov, vzorkovníky rôznych druhov károvaných materiálov. Žiaci diskutujú, zapájajú sa do rozhovoru, zopakujú si predchádzajúce učivo, čím učitel' nadviaže na tému vyučovacej hodiny ( $v$ v počte štyroch vyučovacích hodín\}, „Návrh modelu sukne z károvaného materiálu“.

Žiaci vytvoria štyri skupiny po troch žiakov, rozdelia sa do skupín spontánne. Prácou v skupinách sa budú žiaci podiel'at' na tvorbe návrhov pružnejšie, budú sa doplńňat', nabádat', vytvárat' množstvo kombinácii, zároveň aj skupiny medzi sebou.

Expozičná etapa (16 min). Zadanie problémovej úlohy: „Zhotovit’ návrh modelu sukne z károvaného materiálu“. Aplikovaním problémového výkladu učitel' názorne prezentuje žiakom tému učiva pomocou prezentácie v PowerPointe. Heuristickým rozhovorom zaujmeme žiakov, prezentujeme danú tému (rozdelenie druhov sukne, stručná charakteristika jednotlivých druhov sukní). Žiaci pozorne počúvajú, pozerajú návrhy a nákresy sukne. Žiaci majú možnost' sa aktívne zapájat' do prezentovania učiva vyučujúcim. Vel'ký dôraz kladú na možné návrhy modelov sukní, slovne opíšu modely a rôzne technologické postupy zhotovenia modelov sukní. Žiaci systematicky pozorujú a vnímajú prezentáciu obsahu učiva učitel’om, ktorý aktívne zapája žiakov do diskusie.

Fixačná etapa $(90$ min). Problémová úloha pre žiakov „Vypracovanie úloh s uplatnením faktorov tvorivosti“. V danej etape je vel'mi dôležité zopakovat' všetky nosné informácie, zadania a úlohy. Žiaci v skupinách a začínajú pracovat' - tvorit', navrhovat' modely sukní. Učitel' plní funkciu pozorovatel'a, prácu žiakov dopíňa stručnými pokynmi, ktoré by mali povzbudzovat', motivovat' a nabádat' žiakov. V tejto etape žiaci vytvárajú nákresy, návrhy, opisy a technologické postupy novovznikajúcich modelov.

Zadanie úlohy žiakom: Navrhnite čo najväčší počet rôznych tvarov sukní.

Riešenie úlohy: Žiaci sa vzájomne sa doplńajú, čo jeden navrhne, druhý doplní o d'alší prvok. Všetky nápady dôsledne zaznamenávajú, kreslia, zapisujú. Farebný károvaný materiál uplatňujú na rôznych návrhoch sukne:

1. Dvojdielna sukňa strihaná $\mathrm{s}$ károm kolmo, $\mathrm{v}$ dolnej časti našitý zvonový volán.

2. Dvojdielna sukňa s rovným sedlom, vzor na sedle strihat’ šikmo.

3. Sukňa so sedlom strihaným vodorovne, káro kolmo, spodnú čast’ sukne strihat šikmo a nariasit' do sedla.

4. Sukňa členená s asymetrickým sedlom, kombinovat’ otočenie károvaného vzoru.

5. Sukňa strihaná kosmo, s rázporkami v bočných krajoch.

6. Osemdielna sukňa, tvarované diely sukne v dolnej časti, čím vytvárajú ozdobný volán. 


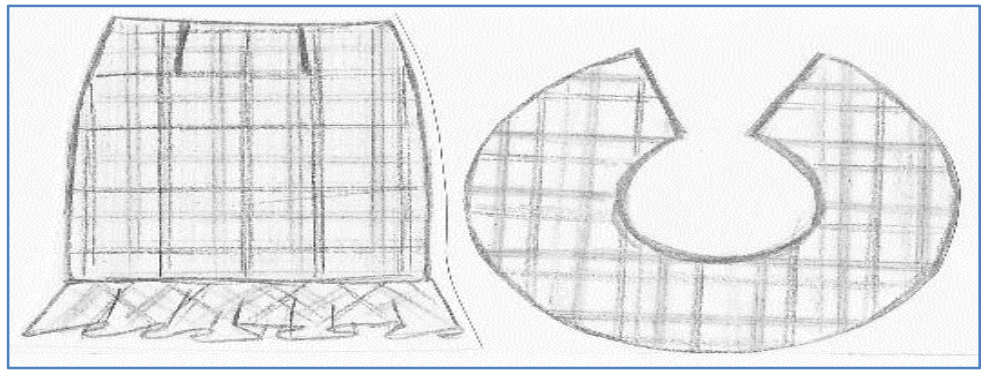

Obr. č. 1: Návrh sukne (úloha zameraná na fluenciu)

Skupiny žiakov majú tvorit’ rôzne varianty sukne. Zatial' pracujú v skupinách, pri práci sa vzájomne dopíňajú. Snažia sa vytvorit' čo najväčšie množstvo nápadov. V tejto časti vyučovacej jednotky môžeme pozorovat' sút'aživost' žiakov medzi sebou.

V návrhoch sukne s prvkami flexibility žiaci navrhujú a opisujú modely, kde je hlavnou úlohou jeden druh strihu sukne vhodne skombinovat' s riešením károvaného materiálu $\mathrm{v}$ rôznych smeroch, čím vznikne množstvo variantov. Ide tu o schopnost' žiakov vytvárat' rôznorodé riešenia jedného základu v iných obmenách. Platí tu pravidlo navrhnutia čo najviac a najrozmanitejších kombinácií nápadov.

Úloha žiakom: Každá skupina si vyberie jeden strih sukne a vymyslí alternatívny tvar sukne podobný základnému strihu sukne.

Vypracovanie úlohy: Prvá skupina si vybrala rozšírenú líniu a modelovú úpravu v tvare šest'dielnej sukne vytvorila v nasledovných variantoch.

1. Diely sukne vystrihnút' $v$ tvare rovnoramenných lichobežníkov a napasovat' károvaný vzor.

2. Diely sukne v tvare lichobežníka s jednou stranou kolmou, vzor je kolmý a na druhej strane šikmý, vzor sa nenapasuje.

3. Diely sukne v tvare rovnoramenného lichobežníka, ale zošité len z časti, vytvárajú vo švoch rázporky.

4. Diely sukne strihat' striedavo kolmé lichobežníky a lichobežníky strihané kosmo, vyjde striedavo jeden diel kolmý, jeden šikmý, je ich šest', budú sa striedat', vzor netreba napasovat'.

5. Diely sukne strihat' všetky kosmo vzor kára sa dá napasovat'. 


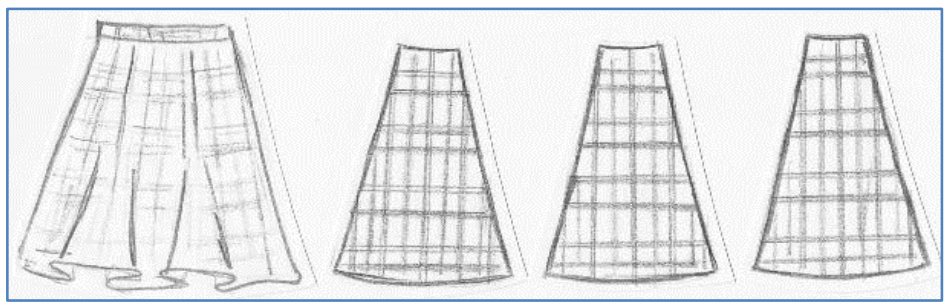

Obr. č. 2: Návrh sukne (úloha zameraná na flexibilitu)

Originalita $v$ tvorbe návrhov sukne znamená schopnost' žiakov vyprodukovat' niečo neobvyklé, netradičné. Vol'nost' fantázie a jej uplatnenia sa v realite najviac oceňuje.

Úloha žiakom: Navrhnite vtipné, bystré, nápadité sukne, čo doteraz ešte nikto nevymyslel.

Odozva žiakov: Žiaci v tvorbe návrhu sukne z károvaného materiálu dali kreativite úplnú vol'nost', vytvorili, uplatnili a zdokumentovali netypické modelové riešenia:

1. Rôzne netypické sukne so záhybmi, v kombinácii so sedlom, strihat' vzor kára $\mathrm{v}$ rôznych smeroch a kombinovat' vel'kost' a farebnost'.

2. Sukňa prestrihnutá šikmo od pravého bočného okraja k l'avému bočnému okraju, na dolný okraj našit tvarovaný polkruhový volán, vzor kára zaujme na pohl’ad.

3. Model sukne strihaný atypicky od bočných okrajov do stredu sukne kosmo, bočné diely kolmo.

V tejto tvorivosti sa uplatnilo vel'a návrhov ako originálne, možností riešenia a návrhov je vel'mi vel’a, žiakom sa práca darila.

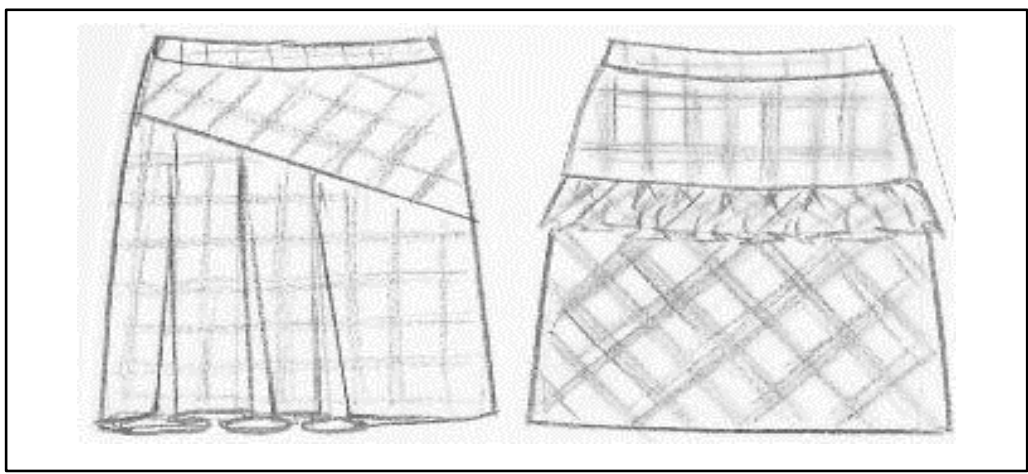

Obr. č. 3: Návrh sukne (úloha zameraná na originalitu)

Redefinícia je doplňujúci faktor tvorivosti v návrhu sukne. Je to schopnost' žiakov zmenit' význam a použitie predmetov, alebo ich častí, novým spôsobom, iným ako doteraz zaužívaným. 
Úloha žiakom: Navrhnite niečo nezvyčajné z materiálu v tvare vel'kého zrezaného kužel’a. Vytvorenie návrhu žiakmi: Túto úlohu realizovali žiaci prostredníctvom vyhotovenia návrhu a nákresu $\mathrm{z}$ tvarovaného materiálu $\mathrm{v}$ tvare zrezaného rozloženého kužel'a. $\mathrm{V}$ našom prípade je to tvarovaný materiál, ktorý môže byt' použitý ako zavinovacia sukňa, po prípade aj navlnená sukňa, ak sa vystrihne materiál širší. Pri použití na sukňu sa našijú pútka na navlečenie opasku, šnúrky na uviazanie a podobne. Riešení návrhov materiálových kombinácií je vel’a.

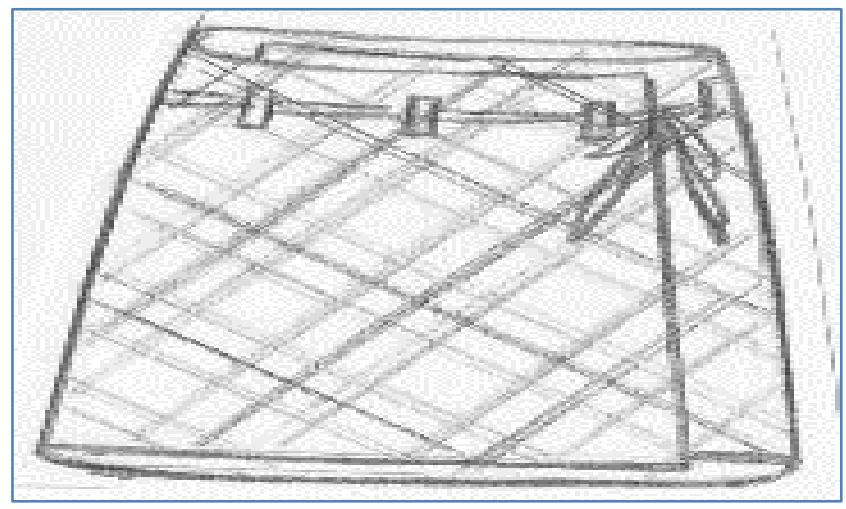

Obr. č. 4: Návrh sukne (úloha zameraná ma redefinovanie)

Nasledujúcim faktorom pri tvorbe návrhov sukne môže byt’ aj elaborácia. Chápe sa ako schopnost' žiakov vypracovat' detaily riešení, z ktorých sa skompletizuje celok. Žiaci majú $\mathrm{k}$ dispozícii károvaný materiál rôznej vel'kosti a farby vzoru.

Úloha pre žiakov: K modelu sukne vytvorte praktické aj efektívne doplnky na zimné a jarné obdobie.

Žiaci v skupine navrhujú, kreslia jednotlivé doplnky k sukniam. Dospeli k spoločným vytvoreniam týchto návrhov:

1. Sukňa strihaná kosmo $\mathrm{z}$ dvoch dielov, $\mathrm{k}$ nej doplnky šál, taška, šatka v tvare trojuholníka, všetko farebne skombinované.

2. Sukňa $\mathrm{z}$ rovného širokého pásu materiálu naskladaná, previazaná viazačkou, $\mathrm{k}$ tomu doplnky, štucne na nohy nariasené, z menšieho rovného tvaru materiálu a šál. Vhodne sa všetko kárované doplní s jednofarebnými pančucháčmi a tričkom.

3. Veselá farebná sukňa evokuje v mladých tvorcoch radost', nápaditost', veselé farby slnka, leta, v pestrých károvaných materiáloch, vyčarujú jednoduchú pohodlnú sukňu $\mathrm{v}$ páse s navlečenou gumou, mierne rozšírený strih a našité malé ozdobné volániky, (podobnou technológiou zhotovená čelenka do vlasov).

Riešenie úlohy zadania károvanej sukne s prvkami senzitivity, predstavuje citlivost' na problémy a schopnost' žiakov rozpoznat' praktické problémy alebo predvídat' potreby, 
dôsledky situácie, vidiet' ich tam, kde ich iní bežne nevidia. Úloha pre žiakov: Navrhnite zhotovenie sukne z károvaného materiálu pre rôzne typy ženskej postavy. Skúste navrhnút' modely pre postavy $\mathrm{s}$ väčšími rozmermi, menšími telesnými rozmermi, ale aj pre bezproblémovú súmernú postavu.

Návrhy riešenia žiakov:

1. Navrhujeme tmavšie farby sukne (väčšia postava),

2. Podobná situácia na riešenie môže nastat' aj pri malej postave, ktorú treba opticky zvýraznit', naskladaná sukňa so sedlom, záhyby primeranej vel'kosti, farebnost' materiálu veselšia, oživit' červenou farbou.

3. Jednoduchá károvaná sukňa, pretvorená do šest'dielnej tvarovanej nohavicovej sukne.

4. Návrh tvarovanej nohavicovej sukne z tvarovaného strihu štvordielnej sukne, diely sa strihajú v tvare zrezaného kužel’a.

Možností a nápadov riešenia je vel'mi vel’a, žiaci pri riešení takýchto problémových úloh nemali vel'ké problémy. Táto posledná čast' zadania a vypracovania problémovej úlohy sa im vel'mi páčila.

Diagnostická etapa (16 min.). Učitel' hodnotí výkony žiakov. Zvolí slovné hodnotenie a povzbudenie žiakov v tvorivej činnosti. Každej skupine oznámi klady a zápory ich modelových návrhov. Upozorní ich aj na vzniknuté nedostatky, aby sa v d’alšej časti vyučovania nefixovali a boli odstránené.

Aplikačná etapa (30 min.). Učitel' zadá žiakom neštandardizovaný didaktický test. Oboznámi ich s obsiahnutou témou v didaktickom teste, s maximálnym dosiahnutým skoré, klasifikačnou stupnicou a pod. Úlohou žiakov je vediet' aplikovat' nadobudnuté teoretické vedomosti a zručnosti z praxe, pri vypracovaní úloh v didaktickom teste.

Záverečná etapa (10 min.). Na záver učitel' stručne zhodnotí priebeh vyučovacej hodiny. Pod’akuje žiakom za aktivitu pri plnení zadaných úloh. S výsledkami z didaktického testu a vypracovaných zadaní učitel' oboznámi žiakov na nasledujúcej vyučovacej hodine. Zhodnotí celý priebeh problémového vyučovania, ktoré prebiehalo vo vytvorených spontánnych skupinách.

\section{Metodické pokyny $k$ štruktúre a priebehu vyučovacej jednotky}

V úvode návrhu a štruktúry vyučovacej jednotky uvádzame použitie vyučovacích metód, vyučovacích zásad a organizačných foriem vyučovania pri navrhnutom type vyučovacej jednotky s využitím problémového vyučovania. Navrhnutá štruktúra vyučovacej jednotky obsahuje jednotlivé fázy. V každej fáze vyučovacej jednotky je uvedený návrh postupu činnosti učitel'a a žiakov pri oboznamovaní sa s témou Dámska sukňa - návrh modelu sukne z károvaného materiálu. Následne uvádzame postup riešenia problémových úloh žiakmi vo fixačnej fáze vyučovacej jednotky. Uvádzame aj možný výsledok riešenia úloh v podobe obrázkov. Jednotlivé zobrazené obrázky sukní predstavujú výsledné riešenie problémovej úlohy.V posledných fázach vyučovacej jednotky uvádzame ako postupuje učitel' 
pri hodnotení výkonov žiakov, pri zadávaní didaktického testu a zhodnotení ciel’ov a priebehu vyučovacej jednotky.

\section{Pedagogický experiment}

Zaoberali sme sa problémom, do akej miery aplikácia problémového vyučovania pomôže žiakom 1. ročníka pri dosahovaní vy̌šíích výkonov v kognitívnej oblasti učenia, respektíve či bude mat' vplyv na stupeň dosiahnutých osvojených vedomosti. To znamená, či žiaci dosiahnu lepšie výsledky vo všetkých úrovniach učenia podla Niemierkovej taxonómie vzdelávacích ciel’ov. V kontrolnej skupine (K) prebiehala výučba tradičným spôsobom (žiaci neboli zapojení do problémového vyučovania) a v experimentálnej skupine (E) žiaci boli zapojení do problémového vyučovania. Po skončení výučby v kontrolnej a experimentálnej skupine sme použili didaktický test pre obidve skupiny na konci prirodzeného pedagogického experimentu. Didaktický test (DT) bol určený pre žiakov 1. ročníka študijného odboru Odevný dizajn. Didaktický test bol test relatívneho výkonu (NR test). Bol použitý neštandardizovaný DT. Pri tvorbe neštandardizovaného didaktického testu sme postupovali podl'a Ivana Tureka (1995). Pedagogický experiment prebiehal v školskom roku 2013/2014. V základnom súbore bolo šest' stredných odborných škôl, v ktorých sa realizoval študijný odbor Odevný dizajn. My sme náhodným výberom (žrebovaním) vybrali do pedagogického experimentu jednu strednú odbornú školu v Trenčianskom kraji. Výskumnú vzorku tvorilo spolu 200 respondentov (žiakov), ktorí boli náhodným výberom rozdelení do kontrolnej a experimentálnej skupiny.

Ho: Výsledky dosiahnuté po skončeni problémového vyučovania $v$ kontrolnej a experimentálnej skupine budú rovnaké.

$H_{I}$ : Respondenti experimentálnej skupiny dosiahnu po skončeni problémového vyučovania vyšši výkon v kognitivnej oblasti v porovnani s kontrolnou skupinou, kde bude výučba realizovaná tradičnými metódami, bez zapojenia žiakov do problémového vyučovania

\section{Analýza výsledkov výskumu}

V tejto časti vedeckej štúdie uvádzame kvantitatívnu a kvalitatívnu analýzu získaných údajov. Kvantitatívna analýza údajov je urobená pomocou uvedených grafov a tabuliek. Kvalitatívnu analýzu získaných údajov realizujeme slovným popisom a zdôvodnením použitia štatistickej metódy na verifikovanie stanovených hypotéz. 


\begin{tabular}{|c|l|l|l|l|l|l|l|l|l|l|l|}
\hline skupina & $\mathrm{N}$ & $\begin{array}{l}\text { priem } \\
\text { er }\end{array}$ & $\begin{array}{l}\text { me } \\
\text { diá } \\
\mathrm{n}\end{array}$ & $\begin{array}{l}\text { mo } \\
\text { dus }\end{array}$ & $\begin{array}{l}\text { Mi } \\
\mathrm{n} .\end{array}$ & Max. & $\begin{array}{l}\text { rozpty } \\
\text { l }\end{array}$ & $\begin{array}{l}\text { Sm. } \\
\text { odch. }\end{array}$ & $\begin{array}{l}\text { Sm. } \\
\text { chyb } \\
\text { a }\end{array}$ & $\begin{array}{l}\text { Šikm } \\
.\end{array}$ & Špic. \\
\hline Kontrolná & 100 & 14,11 & 15 & 16 & 8 & 20 & 12,89 & 3,59 & 0,36 & $-0,16$ & $-1,06$ \\
\hline $\begin{array}{c}\text { Experimen } \\
\text { tálna }\end{array}$ & 100 & 16,30 & 18 & 18 & 9 & 20 & 10,70 & 3,27 & 0,33 & $-0,79$ & $-0,44$ \\
\hline
\end{tabular}

Tab. č. 1: Popisná štatistika

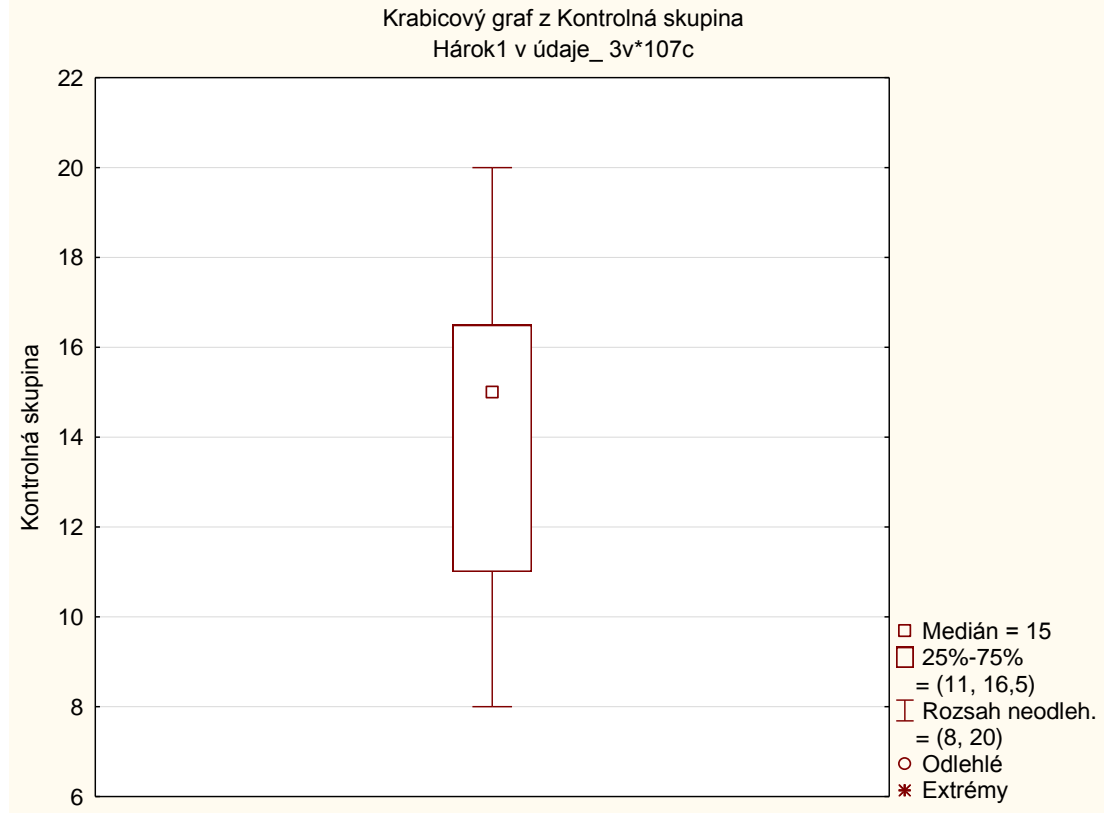

Graf č.1: Medián, kvartilové a variačné rozpätie premenných z výstupného testu v SOŠ (kontrolná skupina)

Už z popisnej štatistiky (Tabul'ka 1) je zrejme, že žiaci stredných odborných škôl experimentálnej skupiny zvládli učivo úspešnejšie ako žiaci kontrolnej skupiny. Vypočítaný aritmetický priemer a smerodajná odchýlka boli vypočítané na intervale spol’ahlivosti: dolný interval: $-95 \%$, horný interval $+95 \%$. Detailnejšiu popisnú štatistiku pre kontrolnú a experimentálnu skupinu uvádzame v tabul'ke 1. 
Variačné rozpätie je určené minimálnou hodnotou 8 a maximálnou 20. Zistili sme, že dosiahnuté výsledky medzi žiakmi sú rozdielne. $Z$ grafu 1 je vidiet', že stredná hodnota súboru pri kontrolnej skupine je rovná 15 .

Kvartilové rozpätie reprezentuje oblast' stredných 50 percent hodnôt premenných, t.j. u kontrolnej skupiny od 11 do 16,5. Či sú tieto výsledky štatisticky významné, sme zistovali analýzou hodnôt. Aby sme mohli vybrat' správnu analýzu hodnôt, najprv sme museli skúmat' predpoklad o normálnom rozdelení pravdepodobnosti náhodných chýb.

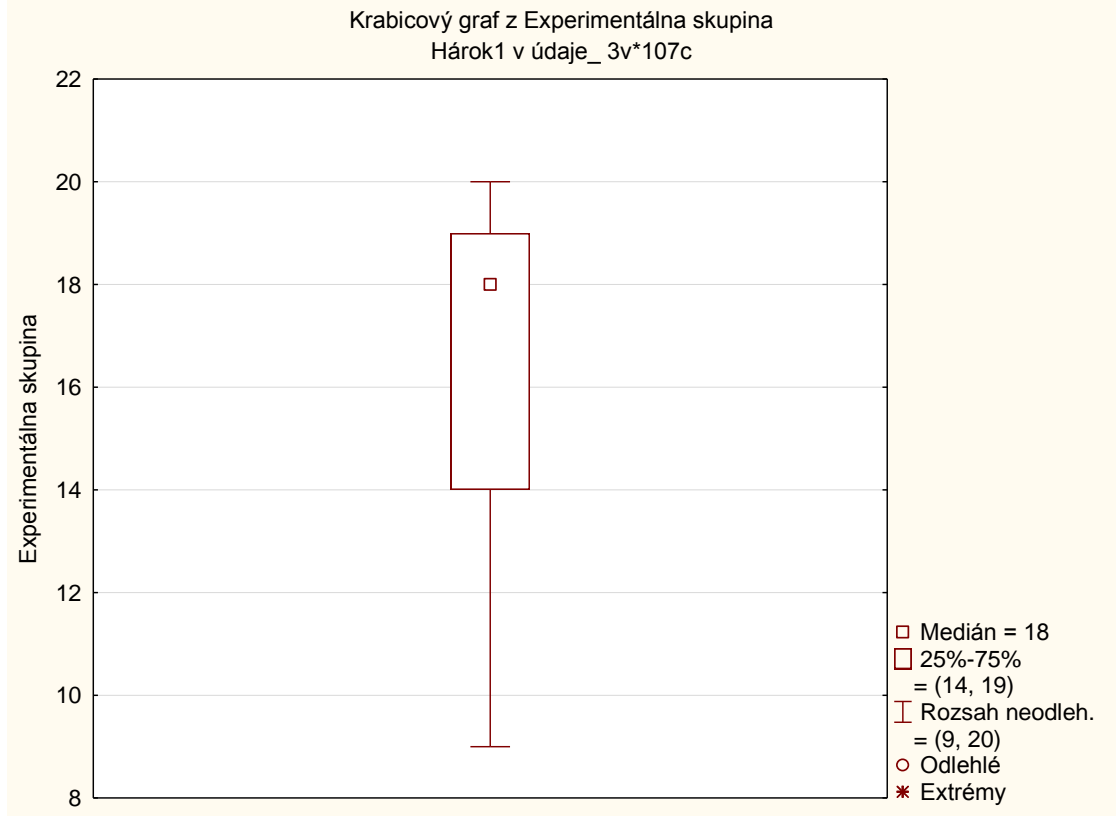

Graf č.2: Medián, kvartilové a variačné rozpätie premenných z výstupného testu v SOŠ (experimentálna skupina)

Pri experimentálnej skupine je stredná hodnota súboru rovná 18 (Graf 2). Pri experimentálnej skupine bolo dosiahnuté najnižšie skóre 9 bodov a najvyššie skóre 20 bodov. Kvartilové rozpätie reprezentuje oblast' stredných 50 percent hodnôt premenných, t.j. u experimentálnej skupiny od 14 do 19 . Graf 3 a 4 rezíduí normality slúži k posúdeniu normality rezíduí, prípadne $\mathrm{k}$ odhaleniu vybočujúcich meraní. V prípade normálneho rozdelenia rezíduí bez vybočujúcich hodnôt ležia všetky body približne na červenej priame, ktoré sú zobrazené v grafoch 3 a 4 . 


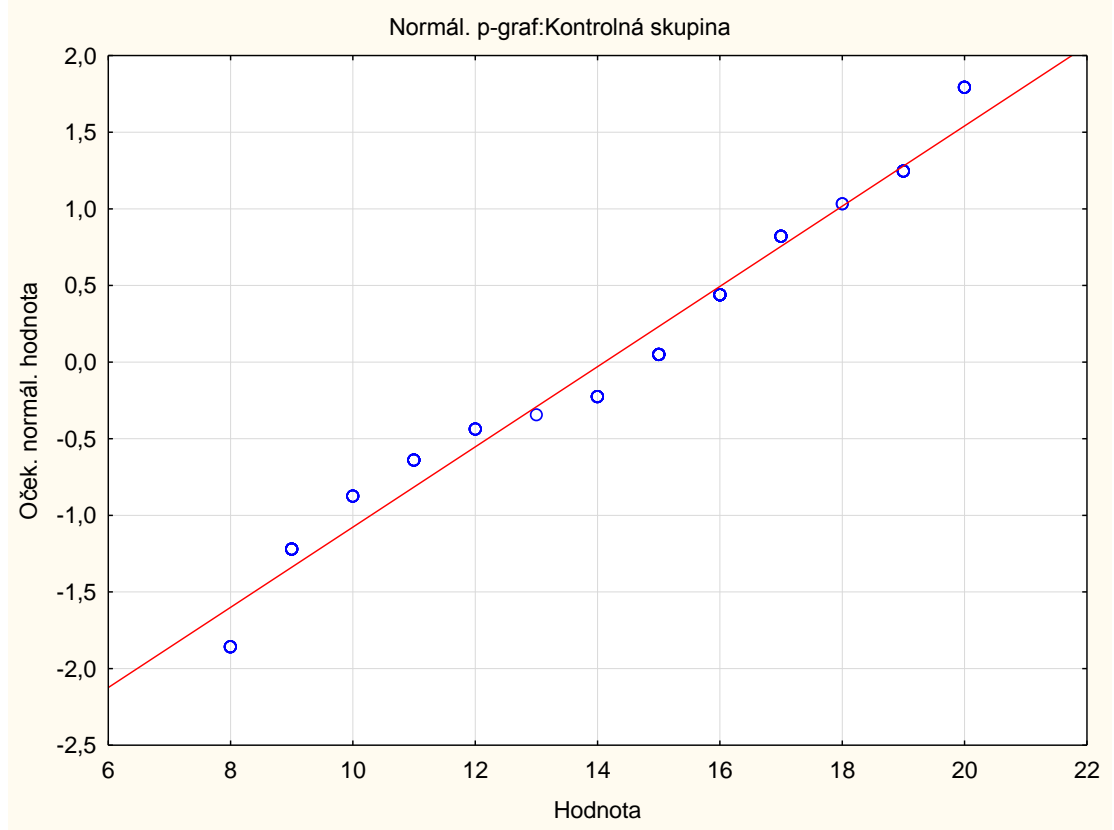

Graf č. 3: Vyhodnotenie normality náhodných chýb-graf normality rezíduí v kontrolnej skupine 


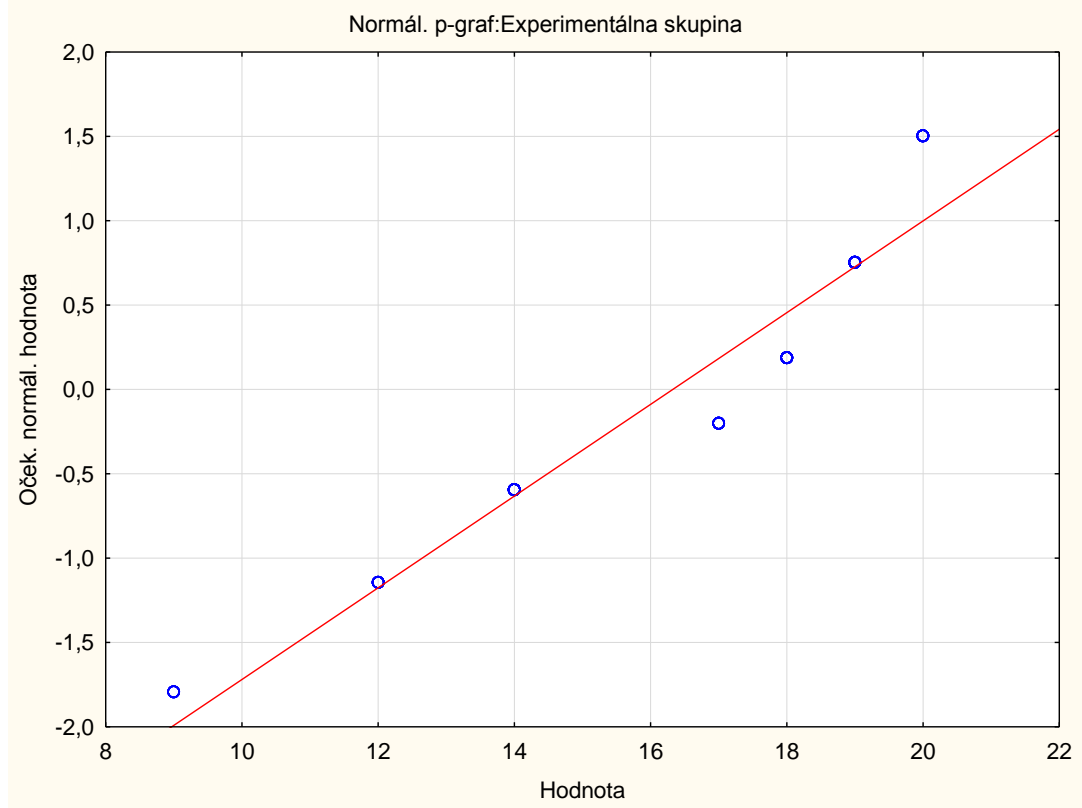

Graf č. 4: Vyhodnotenie normality náhodných chýb - graf normality rezíduí $v$ experimentálnej skupine

Predpoklad o normálnom rozdelení pravdepodobnosti náhodných chýb sme skúmali pomocou grafov normality rezíduí a taktiež porovnaním rozptylov základných súborov. Obidva grafy (Graf 3 a Graf 4) nie sú jednoznačne symetrické. Graf normality rezíduí vytvoril priamku, resp. podoba normálnych pravdepodobnostných grafov by mohla byt' prijatel’ná.

\begin{tabular}{|l|l|l|}
\hline Normality & Kontrolná skupina & Experimentálna skupina \\
\hline Sample name & 100 & 100 \\
\hline Sample size & 14,12 & 16,26 \\
\hline Mean & 3,61 & 3,27 \\
\hline Standard deviation & $-0,17, \mathrm{p}=0,476$ & $-0,77 . \mathrm{P}=0,0024$ \\
\hline Skewness & $1,92, \mathrm{p}<0,0001$ & $2,47, \mathrm{p}=0,2294$ \\
\hline Kurtosis & $15,85, \mathrm{p}=0,0004$ & $9,25, \mathrm{p}=0,0098$ \\
\hline Royston chi - sq & $0,97, \mathrm{~V}=2,56, \mathrm{p}=0,0187$ & $0,92, \mathrm{~V}=6,84, \mathrm{p}<0,0001$ \\
\hline Shapiro - Wilk W & $0,97, \mathrm{~V}^{1}=2,62, \mathrm{p}=0,0274$ & $0,92, \mathrm{~V}^{1}=7,01, \mathrm{p}<0,0001$ \\
\hline Shapiro - Franca $\mathrm{W}^{1}$ &
\end{tabular}

Tab. č. 2: Shapiro - Wilkov test (kontrolná a experimentálna skupina) 
Použili sme Shapiro - Wilkov test (Tabul'ka 2) na zistenie náhodného výberu z normálneho rozdelenia. Zistili sme, že $W \leq W^{\prime}$, v našom prípade je nepravdepodobné, že testovacia vzorka pochádza z normalného rozdelenia. Taktiež vypočítané rozptyly nie sú rovnaké.

\begin{tabular}{|l|}
\hline Variables: Kontrolná skupina, Experimentálna skupina \\
\hline Groups $=2$ \\
\hline $\mathrm{Df}=1$ \\
\hline Total observations $=200$ \\
\hline $\mathrm{T}=18,37$ \\
\hline $\mathrm{p}<0,0001$ \\
\hline Adjusted for ties: \\
\hline $\mathrm{T}=18,56$ \\
\hline $\mathrm{p}<0,0001$ \\
\hline
\end{tabular}

\section{Tab. ̌. 3: Kruskal-Wallisov test}

Na základe zistených skutočnosti (nebol splnený predpoklad o normálnom rozdelení súboru) sme sa rozhodli použit' neparametrický Kruskal - Wallisov test. Kruskal - Wallisov test (Tabul'ka 3) sme použili na zistenie existencie štatisticky významných rozdielov medzi kontrolnou a experimentálnou skupinou. Ked’že sme z popisnej (základnej) štatistiky zistili, že rozdiely medzi skupinami sú rozdielne, d’alej sme potrebovali zistit', či tieto rozdiely medzi skupinami sú aj štatisticky významné. Použitie Kruskal - Wallisovho testu považujeme za opodstatnené a správne.

Nulovú hypotézu zamietame, ak $\mathrm{H} \geq \chi^{2}{ }_{1-\alpha(k-1)}$. Pre hladinu významnosti $\alpha=0,05$ je oblast' zamietnutia určená hodnotou kvantilu $\chi^{2} 1-\alpha(k-1)=\chi^{2} 0,95(1)=3,841$. To znamená, že hodnota testovacej štatistiky sa nachádza $\mathrm{v}$ oblasti zamietnutia nulovej hypotézy. Z toho vyplýva záver, že výkony, ktoré dosiahli žiaci kontrolnej a experimentálnej skupiny sú štatisticky rozdielne. Taktiež vypočítaná $\mathrm{p}$ hodnota je príliš malá a teda nulovú hypotézu zamietame. Záverom môžeme konštatovat', že hypotéza $\mathrm{H}_{1}$ bola potvrdená. Sme si vedomí, že výskumná vzorka nebola vel'ká, preto naše výsledky nemôžeme zovšeobecňovat'. Naše zistenia môžu byt' návodom a inšpiráciou pre vedeckých pracovníkov v oblasti pedagogických vied.

\section{Reflexia vyučovacej jednotky}

Žiaci v študijnom odbore Odevný dizajn riešili problémové úlohy s využitím šiestich faktorov tvorivosti. Žiaci boli spontánne rozdelení do skupín. Každá skupina žiakov pracovala na riešení zadaných problémových úloh. Žiaci vytvárali rôznorodé riešenia. Pri úlohe, ktorá bola zameraná na fluenciu, žiaci navrhovali rôzne tvary sukní. Žiaci sa čo najlepšie snažili vnímat' detaily ( $\mathrm{k}$ modelu sukne vypracovali doplnky $\mathrm{k}$ sukniam), navrhovat' originálne riešenia a taktiež navrhnút' niečo nezvyčajné $\mathrm{z}$ materiálu $\mathrm{v}$ tvare vel'kého zrezaného kužela. Žiaci mali radost’ z práce, každá skupina žiakov prezentovala výsledky svojich riešení. 


\section{Diskusia a závery}

$\mathrm{Na}$ základe nami realizovaného výskumu a prostredníctvom jednotlivých analýz a interpretácií výsledkov môžeme zhodnotit' stanovené ciele empirického výskumu a zhodnotit' potvrdenie stanovených hypotéz. Hlavným cielom výskumu bolo zistit', či problémové vyučovanie vplýva na vedomosti žiakov. Pri vyhodnocovaní jednotlivých úloh v DT sme dospeli k číslu - maximálnemu dosiahnutému skóre u žiakov v kontrolnej a experimentálnej skupine. Dosiahnuté maximálne skóre nám potvrdilo, že medzi skupinami existujú rozdiely. No či sú tie rozdiely aj štatisticky významné sme zist'ovali Kruskal - Wallisovym testom na hladine významnosti 0,05 (95\%). Môžeme konštatovat', že dosiahnuté výkony žiakov sú ovplyvnené aplikáciou problémového vyučovania. Tým sa nám potvrdila aj hypotéza $\mathrm{H} 1$. Z výsledkov sme identifikovali, že žiaci dosiahli vyššie výkony v kognitívnej oblasti pri aplikovaní nami navrhnutého a realizovaného problémového vyučovania v praxi. V budúcnosti je možné empirickú čast' vedeckej štúdie rozšírit' o preskúmanie d’alších čiastkových hypotéz. Skúmali by sme zvyšovanie výkonov žiakov aj $v$ jednotlivých úrovniach učenia podl'a Niemierkovej taxonómie vzdelávacích ciel’ov (zapamätanie, porozumenie, špecifický a nešpecifický transfer). Za dôležité zistenie považujeme aj pozitívne postoje žiakov $\mathrm{k}$ riešeniu problémových úloh $\mathrm{z}$ faktormi tvorivosti (fluencia, flexibilita, originalita, elaborácia, senzitivita, redefinícia). Toto zistenie bolo zrealizované pozorovaním žiakov priamo počas priebehu vyučovacej jednotky. Aplikovaním nových koncepcií vyučovania $\mathrm{v}$ odborných predmetoch $\mathrm{v}$ stredných odborných školách môžeme rozvíjat' aj tvorivost' žiakov. Navrhujeme pokračovat' $\mathrm{v}$ aplikovaní d'alších koncepcií vyučovania do edukačného procesu a následne zrealizovat' teoretickú analýzu i empirický výskum ich efektívneho využitia v praxi. Kvitujeme, že pri zaradení takýchto koncepcií vyučovania je potrebné klást' vel'ký dôraz na správny výber témy a správne navrhnutie štruktúry vyučovacej jednotky.

Novšie koncepcie vyučovania majú svoje miesto a opodstatnenie vo výučbe odborných predmetov v súčasnej škole. My sme navrhli problémové vyučovanie v študijnom odbore Odevný dizajn v SOŠ. Sledovali sme vplyv navrhnutej novšej koncepcie vyučovania na výkony žiakov. Pozorovali sme žiakov ako riešia problémové úlohy priamo počas vyučovacej jednotky. Na základe získaných a spracovaných údajov odporúčame:

- Aplikovat' do vyučovania odborných predmetov d'alšie koncepcie vyučovania,

- Verifikovat' novšie koncepcie vyučovania v edukačnom procese,

- Verifikovat' výkony žiakov aj $\mathrm{v}$ jednotlivých úrovniach učenia podla Niemierkovej taxonómie vzdelávacích ciel’ov.

Netreba zabúdat', že aj novšie koncepcie vyučovania treba aplikovat' do edukačného procesu uvážene a kombinovat' ich s tradičným vyučovaním. Nami navrhnuté problémové vyučovanie a následne jeho verifikovanie v edukačnom procese môže poslúžit' ako vzor pre potenciálne verifikovanie aj ostatných koncepcií vyučovania v edukačnom procese v súčasnej škole. Pri komparácii využívania a verifikovania novších koncepcii vyučovania v SR a v ostatných európskych krajinách môžeme povedat', že ten rozdiel nie je vel'ký. Nielen u nás v SR, ale aj d'alších vyspelých štátoch EÚ sa novšie koncepcie vyučovania efektívne aplikujú do edukačného procesu, a to nielen vo vyššom strednom vzdelávaní, ale už aj v primárnom a nižšom strednom vzdelávaní. 


\section{Literatúra}

Argalacs, M. (1984). Riešime problém od zadania po kontrolu výsledku. Bratislava: Slovenské pedagogické nakladatel'stvo, 72 s. ISBN 978-80-372-6784-2.

Bajtoš, J. (2003). Teória a prax didaktiky. Žilina: Žilinská univerzita, 384 s. ISBN 80-8070130.

Brightman, H. J. (2006). GSU Master Teaching. Program: On Critical Thinking [on - line]. [cit. 10. 01. 2013]. Dostupné na internete:http://www.wku.edu/university experience/essay5.html.

Crowder, N.A. (1960) Automatic Teaching by Intrinsic Programming. In: Lumsdaine, A.A, Glaser, $R$ (editors): Teaching Machines and Programmed Learning: A Source Book. Washington: National Education Association. ISBN 80 - 9878-140-5.

Chajdiak, J., Rublíková, E., Gudába, M. (1994). Štatistické metódy v praxi. Bratislava: STATIS. ISBN 80-85659-02-6.

Jurčová, M. (2003). Tvorivost’ v každodennom živote a vo výskume. Bratislava: IRIS, $255 \mathrm{~s}$. ISBN 80-8569-54-6.

Kirschner, P. A., Sweller, J., and Clark, R. E. (2006). Why minimal guidance during instruction does not work: an analysis of the failure of constructivist, discovery, problembased, experiential, and inquiry-based teaching. In: Educational Psychologist 41 (2), p. 75 86.

Králiková, A. (2013). Nové prístupy vo vyučovaní odborného predmetu technológia v SOŠ, téma: Dámska sukňa (Diplomová práca). Banská Bystrica: FPV UMB.

Niemierko, B.: (1979). Taxonómia celów wychowania. In: Kwartalnik pedagogyczny. roč. 24 , č. 2, 58-69 s.

Kyriacou, Ch. (1996). Kličové dovednosti učitele. Praha: Portál, 152 s. ISBN 80-7178-022.

Lerner, I. J. (1974). Prblemnoje obučenije. Moskva: Znanije. 214 s. ISBN 70-8596-514.

Petlák, E. (2004). Všeobecná didaktika. Bratislava: Iris, 318 s. ISBN 80-89018-64.

Okon, W. K. (1966). K základiom problémového učení. Praha: SPN, 222 s. ISBN 80-7985145.

Petty, G. (1996). Moderní vyučování. Praha: Portál, 145 s. ISBN 80-7178-070-7.

Singule, F. (1990). Americká pragmatická pedagogika. Praha: SPN, 197 s. ISBN 80-0420715-4.

Симоненко, Самородский, Тищенко. (2012). Технология. Технический труд. 7 класс. Учебник. ISBN 90-4589-214.

Turek, I. (2008). Didaktika. Bratislava: Iura Edition., s. 595. ISBN 978-80-8078-198-9.

Turek, I. (1995). Didaktické testy. Bratislava: MPC, 1995. ISBN 748-80-8074-8. 